\title{
An Analysis of Trends in Foreign Direct Investment Inflows to Africa
}

\author{
Edward E. Marandu ${ }^{1}$, Paul T. Mburu ${ }^{1} \&$ Donatus Amanze ${ }^{1}$ \\ ${ }^{1}$ University of Botswana, Faculty of Business, Marketing Department, Botswana \\ Correspondence: Paul T. Mburu, University of Botswana, Faculty of Business, Marketing Department, Botswana.
}

Received: November 15, 2018

Accepted: December 5, $2018 \quad$ Online Published: December 11, 2018

doi:10.5430/ijba.v10n1p20

URL: https://doi.org/10.5430/ijba.v10n1p20

\begin{abstract}
This study examines the trends in Foreign Direct Investment (FDI) inflows to Africa, with the ultimate aim of proposing implications for policy action. The main source of data for this study is the UNCTAD (2018) database which at the time of the study contained FDI data from 1990 to 2016. The findings show that, although Africa is in dire need for FDI due to scarcity of capital, it is not able to attract as much FDI compared to advanced countries and other developing regions. The little FDI that comes to Africa is concentrated sub-regionally and country-wise. Region-wise, most FDI is concentrated on Southern Africa followed by Northern Africa with East Africa and Central Africa at the bottom. Country-wise, the two main recipients of FDI in each sub-region are Angola and South Africa (Southern Africa); Egypt and Morocco (North Africa); Nigeria and Ghana (West Africa); Tanzania and Ethiopia (East Africa) and Congo and the Democratic Republic of Congo (Central Africa). The FDI that comes into the continent is further concentrated in the primary (extractive) sector. As a result the benefits to the region have not been as significant as in East Asia where FDI was mainly into the secondary (manufacturing) sector. It is concluded that, FDI is a growth point that countries can count on as a source of resources for development, however, Africa need to change the approach adopted in promoting FDI, which focuses on providing incentives to creating a domestic environment conducive to entrepreneurship and business in general.
\end{abstract}

Keywords: FDI, foreign direct investment, Africa, trends, sectors, extractive

\section{Introduction}

This paper examines the major trends and patterns of foreign direct investment (FDI) inflows to the African continent. It is based on the widely recognized assumption that foreign direct investment FDI produces economic benefits to host countries. FDI offers capital, technology, foreign exchange, competition, enhances access to foreign markets (World Bank, 1999; Nuno \& Fontoura, 2007; UNCTAD, 1991) as well as boosting domestic investment and innovation (Brooks, Fan, \& Sumulo, 2003). It follows that developing countries, most of which operate in the poverty trap, with low savings rate and low investment rate may escape from the trap by attracting capital from abroad in the form of FDI (Hayami, 2001).

\subsection{The Problem}

African nations have very low savings rates because of absolute poverty. This makes it hard to finance investments needed for growth and development. Empirical evidence suggests that given the rate of population growth on the continent, to reverse the spread of poverty Africa would have to achieve rates of economic growth of between 7 and 8 percent, well above twice that of the population as a minimum requirement (Loots \& Kabundi, 2012; Anyanwu \& Erhijakpor, 2003). Such a growth rate needs investment of about 25 per cent of GDP per annum: however, with the current rate of about 9 per cent, the financing deficit amounts to 16 per cent of GDP (Ndulu, Chakraborti, Lijane, Ramachandran, \& Wolgin, 2007). FDI can close this gap and arrest and reverse the spread of poverty.

The literature on FDI flows to Africa is scanty and focused on determinants (Cockcroft \& Riddell, 1991; Rogoff \& Reinhart, 2003; Bende-Nabenfe, 2002; Akinlo, 2003; Asiedu, 2002; Lemi \& Asefa, 2003; Dupasquier \& Osakwe, 2005) of FDI to the continent, with little discussion of how it is distributed. This paper attempts to overcome this limitation by studying trends that may help identify what needs to be done at the national, regional and international level in order to boost FDI flows to Africa.

\subsection{Objectives of the Study}

The broad objective of this study is to examine the trends in Foreign Direct Investment inflows to Africa, with the 
ultimate aim of proposing implications for policy action. In the light of this objective, the issues to be studied revolve around seeking answers to the following questions:

1. Where does Africa fit in the global foreign direct investment picture?

2. What is the continent's share of the global FDI?

3. Which regions attract most FDI in Africa?

4. In which sectors is the FDI invested?

5. Who are the African beneficiaries of these flows?

6. What should be done to ensure attraction of FDI to the Continent?

Answers to these critical questions should be helpful in unpacking the African-specific FDI trends in order to get a clearer and more substantiated understanding of the current trends, thereby facilitate formulation of turnaround strategies for the continent.

\subsection{Background to the Problem}

This section presents, in a nutshell, a historical evaluation of the African political-economic environment as it evolved from the 1960s to the present, which provides the context for the FDI issues discussed in this study. It should be of interest to the reader not familiar with the continent.

Following political independence of African countries during the 1960s, the new leadership, based on history, ideology and cold war politics, was sceptical about the value of free trade and foreign investment. This view reflected fears that FDI could push indigenous firms into liquidation due to competition and lead to the loss of sovereignty. Consequently, several countries in the continent imposed trade barriers and foreign exchange controls as part of a policy of import-substitution industrialization and protecting local entrepreneurs. The results were the exact opposite: this inward-looking strategy discouraged trade as well as FDI and had adverse effect on economic growth (Dupasquier \& Osakwe, 2005; Rodrik, 1998). While GDP income increased in other developing regions, Africa on the other hand, experienced an average decline (World Bank, 2003).

After the unsatisfactory economic performance by African nations beginning in the late 1970s up till the mid-1990s, it became clear that economic reforms in favour of outward-looking development programs were needed to halt the deteriorating economic conditions. The reforms created incentives that generated more savings, domestic and foreign investment, exports, efficient functioning of markets with a view to unleashing private initiative and enterprise. Available statistics show that the average growth rate of real GDP per capita which was negative $0.9 \%$ over the period 1975-84 rose to positive $0.7 \%$ in the period 1995-2002, average of $6.68 \%$ between 2002 and 2007, 4.37\% between 2008 to 2015 before slowing down to $1.97 \%$ between 2016 and 2017 as per World Bank (2017) as indicated by Figure 1. It appears that the modest increase in FDI inflows to the African continent coincided with a turnaround in the declining economic growth.

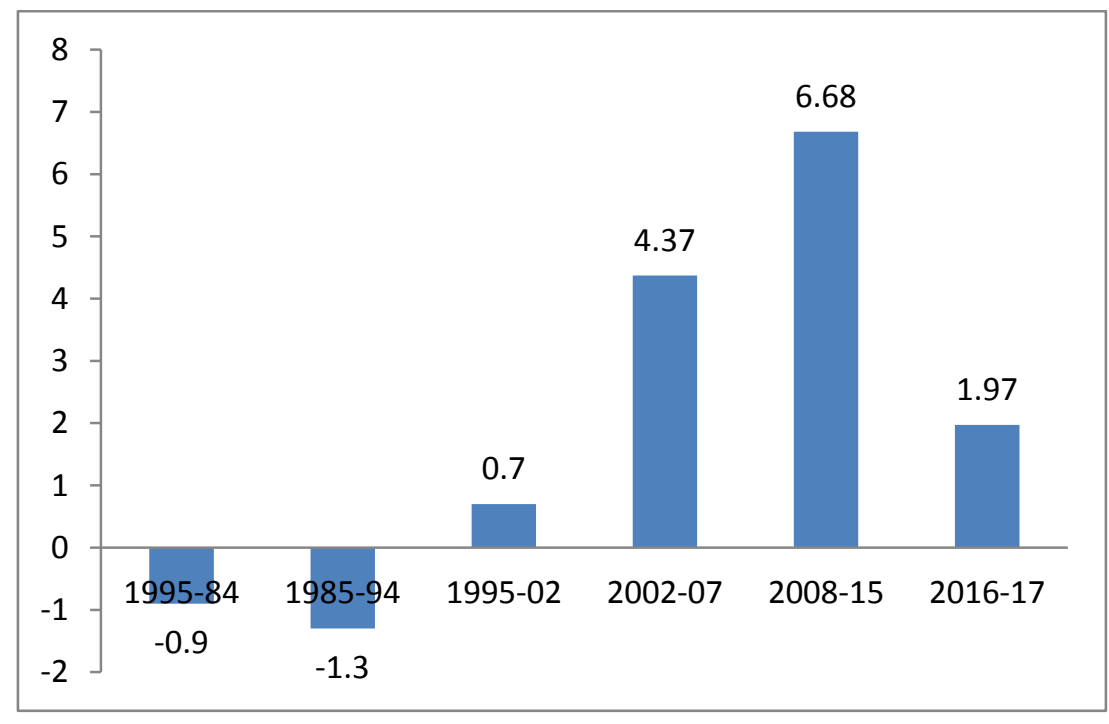

Figure 1. Mean growth rate of real GDP in Africa

Source: World Bank, world development indicators, 2017 
It should be emphasized, however, that the improved overall performance still falls short of fulfilling the needs of the continent. This is so because aggregate performance conceals differences in individual country circumstances and the modest good performance falls short of what is required to bring about visible gains in the living standards of a significant proportion of the population suffering from absolute poverty. The progress made so far is not enough for sustained growth and development because for most countries in the continent, the population growth rate is in excess of 2\% every year (Population, 2018)

It is concluded that until recently FDI was not fully accepted by African leaders as a vital feature of economic development. They suspected that FDI would have negative consequences such as the killing of the infant local industry (Pavithra, 2012) and loss of sovereignty (Bezuidenhout \& Kleynhans, 2015). These fears were not unfounded: it is now commonly accepted that foreign oil firms in Nigeria have had perverse effects on the local environment (EIA, 2003). Although most of the concerns of the African leaders are legitimate, experience has shown that if a host country has good governance and creates an environment conducive to investment, FDI can play a significant role in its development efforts (Dupasquier \& Osakwe, 2005). Thus FDI can play several important roles (Anyanwu, 2003; Dupasquier \& Osakwe, 2005) in Africa's development efforts, including:

- Supplementing domestic savings: Since African countries have low savings rates, which make it difficult to finance investment projects FDI can fill this resource gap.

- Employment generation: By providing additional capital to African countries, FDI can directly create new employment opportunities and indirectly through increased linkages with domestic firms.

- Integration into the global economy: Openness to FDI enhances international trade thereby contributing to the integration of African countries into the global economy.

- Transfer of modern technologies: Foreign firms typically make significant investments in research and development. As a result, they tend to have superior technology relative to firms in developing countries. FDI can provide African countries with cheap access to new technologies and skills thereby enhancing local technological capabilities and their ability to compete on world markets.

- Enhancement of efficiency: Opening up an economy to foreign firms increases the degree of competition in product markets hence inducing domestic firms to allocate and use resources more efficiently.

- Raising skills of local manpower: Through training of workers and learning by doing, FDI raises the skills of local manpower thereby increasing their level of productivity.

\subsection{Theoretical Framework}

The section presents two selected theories that would help suggest the motives or reasons for investing abroad. This should be helpful in inferring the implications of these theories for what one might observe on the ground in Africa.

Perhaps the early concept of foreign direct investments (FDI) can be traced back to Ohlin, (1933) who build on the Ricardo's classical theory of comparative advantage. Heckscher-Ohlin attempted to explain how and why FDI is attracted to some economies and not others. The theory is built on the development of the concept of international movements of capital for international trade due to differences in resource endowments among counties. The theory essentially says that a country would produce for local consumption and export products that utilize their abundant and cheap factor(s) of production and import products that utilize the country's scarce factor(s). The implication for FDI is that firms seek places where there is abundance of resources to invest their capital.

The second theory (Ohlin, 1933) is the eclectic theory (Dunning, 1977), popularly known as OLI, is an integration of three theories. The theory posits that firms undertake FDI when the advantages of Ownership, Location and Internalization combine to make it appealing to undertake FDI. Ownership advantage is the benefit that a company gets due to its ownership of some special asset, such as a powerful brand, technical knowledge or management ability. Location advantage is the benefit of setting an economic activity in a place because of the natural or acquired characteristics of the locale. Internalization advantage is the gain that arises from undertaking a business activity in-house rather than leaving it to a relatively inefficient market. According to Nayyar (2014), the theory therefore holds that FDI is the result of firms possessing Ownership specific (income generating) advantages $(\mathbf{O})$ that they want to exploit in foreign Locations (L), which they cannot profitably do except through Internalization (I).

According to one author (Kurtishi-Kastrati, 2013) FDI will take place when Ownership, Location, and Internalization advantages come together to make it appealing to undertake FDI. The Ownership advantage mostly determines the "why" decision, Internalization advantages mostly determine the "how" decision and the Location advantage mostly determines the "where" decision. FDI is motivated mainly by the possibility of high profitability in growing markets, 
along with the possibility of financing these investments at relatively low rates of interest in the host country (Kalotay, 2006).

This theory further introduces the concept of a "seeker" (Dunning \& Lundan, 2008) in which firms or an individual is described as a 'seeker' looking into investing and is normally driven by four motives. First, there are the "natural resource seekers", who are looking for abundant natural resources at a lower cost than that of their home country. Second, there are "market seekers" who are interested in gaining access to larger markets. Third, there are "efficiency seekers", who are looking for investment in different countries so as to gain economies of scale. Finally, there are "strategic asset seekers" who want assets that will help them strengthen their competitiveness in the global marketplace.

We therefore postulate that the trend of the flow of FDI in Africa follows a pattern, as dictated by the combination of seekers and eclectic concepts as indicated in Figure 2. Firms seek fresh supply of natural resources, attractive markets and advantages of internalization. Need for efficiency such as cheap labor, advance technologies and other strategic assets can also lead to FDI, seeking for comparative advantage. However not all locations or countries can offer comparative advantage of the same degree. As such firms seek locations or countries that own natural resource, market or efficiency advantages as destination for their FDI. They also look for sectors within those locations that can offer the maximum internalization benefit without compromising the integrity and patent capital, as safe sectors for investing FDI.

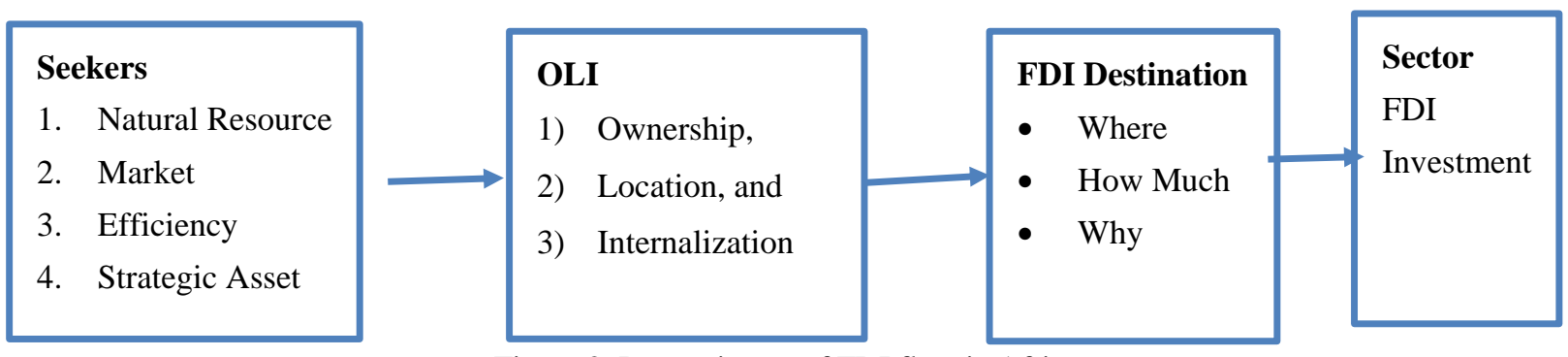

Figure 2. Determinants of FDI flow in Africa

Source: The Authors

It is postulated that countries attract FDI from those firms looking for market expansion, efficiency and natural resources. The rate and the amount of attraction is dependent on the availability of the above factors and that the sectors that attract the FDI in those countries are those that allow the internalization.

\subsection{Research Methodology}

1) Research Design: The paper adopted a quantitative desktop research approach.

2) Sample: To avoid sample selection bias, all 56 African countries were included.

3) Data: Data on FDI for the 27 year period 1990-2016 is used for the study. This was the latest data available at the time of writing. The measure used to gauge FDI in this study is FDI annual flows rather than the accumulated FDI stock.

4) Data Collection Method: The study is based on secondary data from UNCTAD, FDI/MNE database 2017 Annex Table 1 (UNCTAD, 2018). In this database FDI is described as an investment involving a long term relationship and reflecting a lasting interest and control by a firm based in one country, into a firm based in another country.

5) Data Analysis Method: The general approach for the data analysis was to undertake analysis that follows one another on increasing level of detail from the general or global, followed by regional analysis and eventually focus on Africa as a whole, African sectors and individual African countries. Specifically, data analysis involved taking 5-year averages from 1990 except for the last two years which is an average of 2015 and 2016 (two years).

6) Data Presentation: Data for the study were mainly presented in tabulated format and in a few circumstances graphs were employed to ensure pictorial elucidation. 


\section{Findings}

This section presents the salient findings of the study. The presentation is organized to flow systematically from global, regional, Africa, sub-regional, country and finally analysis by sector all in the context of Africa.

\subsection{World FDI Inflows}

In the 27-year period between 1990 and 2016, global inward FDI flows increased almost 8.8 times from an annual average of US $\$ 199,366.30$ million in the period 1990-94 to an annual average of US\$1,760,212.10 million in the two-year period 2015-16 (Figure 3). The tremendous increases in FDI may be explained by the rapid advances in technology especially in transport and communication (Dupasquier \& Osakwe, 2005).

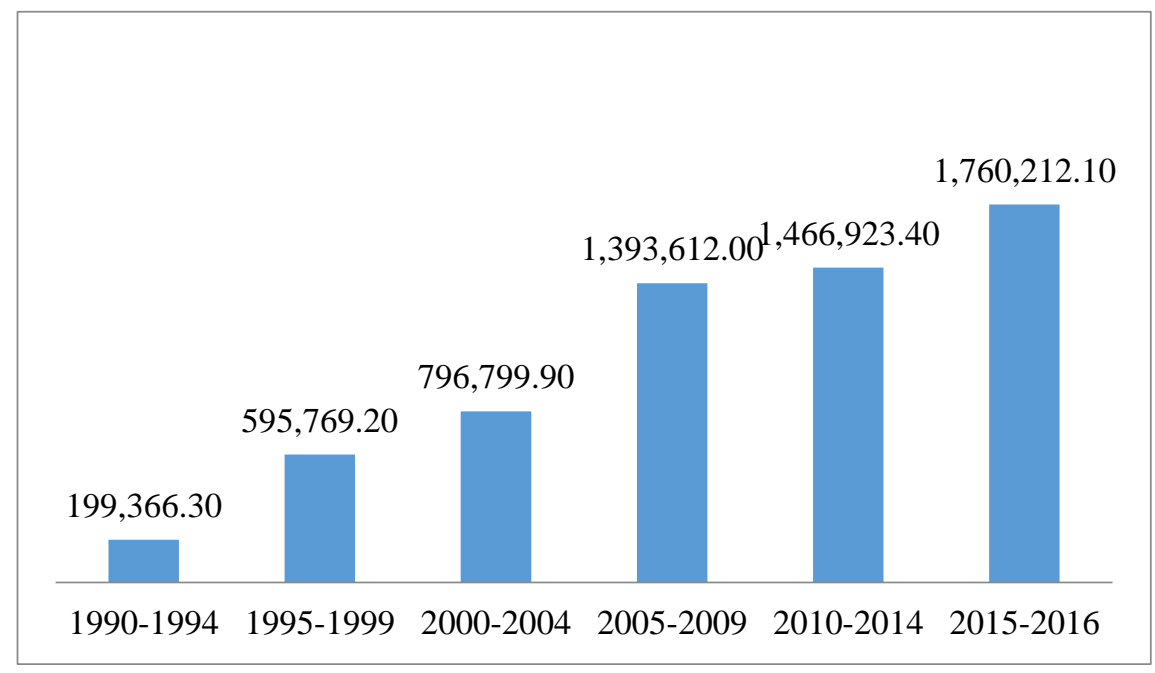

Figure 3. Average world FDI inflows (US\$ Millions)

Source: Computed by Authors from UNCTAD (2018)

\subsection{Regional Global FDI Inflows}

In terms of global regional distribution, developed economies are the recipients of the bulk of world FDI inflows. Specifically, during the period 1990-2016 around 63\% of world FDI flowed to advanced countries, $34 \%$ to developing countries and 3 per cent to transition economies (Table 1).

Table 1. Distribution of world FDI inflows

\begin{tabular}{lccccccc}
\hline & $1990-1994$ & $1995-1999$ & $2000-2004$ & $2005-2009$ & $2010-2014$ & $2015-2016$ & 27-Year Average \\
\hline $\begin{array}{l}\text { Developed } \\
\text { economies }\end{array}$ & $69 \%$ & $71 \%$ & $71 \%$ & $61 \%$ & $49 \%$ & $57 \%$ & $\mathbf{6 3 \%}$ \\
$\begin{array}{l}\text { Developing } \\
\text { economies }\end{array}$ & $31 \%$ & $28 \%$ & $27 \%$ & $34 \%$ & $46 \%$ & $40 \%$ & $\mathbf{3 4 \%}$ \\
$\begin{array}{l}\text { Transition } \\
\text { economies }\end{array}$ & $1 \%$ & $1 \%$ & $2 \%$ & $5 \%$ & $5 \%$ & $3 \%$ & $\mathbf{3 \%}$ \\
\hline
\end{tabular}

Source: Computed by authors from UNCTAD, world investment report (2018)

\subsection{FDI Inflows to World Developing Regions}

Throughout the 27-year period covered by this study Africa has not been a major recipient of FDI and lags behind other regions of the world (Table 2). On an annual average basis, Africa's share of global FDI inflows is small, averaging 3\%, throughout the period. It should be noted that this figure is below the average for LA\&CA which stands at 9\% and way below that for Asia \& Pacific Region which stands at 22\%. Therefore, Africa currently attracts a relatively small share of global FDI. 
Table 2 also covers the share of inflows among the main developing regions. Africa's share within the group is again relatively small averaging 6\%. Again it should be noted that this figure is below the average for LA\&CA which stands at $20 \%$ and way below that for Asia \& Pacific Region which is $64 \%$. The main beneficiary of FDI inflows in the developing world in the study period is Asia.

Table 2. Share of FDI inflows to developing economies

\begin{tabular}{lcccccc}
\hline & \multicolumn{3}{c}{$\%$ share of World FDI } & \multicolumn{3}{c}{$\%$ share of Developing Countries FDI } \\
\hline Period & Africa & LA\&CA & Asia & Africa & LA\&CA & Asia \\
$1990-1994$ & $2 \%$ & $8 \%$ & $21 \%$ & $7 \%$ & $25 \%$ & $67 \%$ \\
$1995-1999$ & $1 \%$ & $10 \%$ & $17 \%$ & $5 \%$ & $36 \%$ & $59 \%$ \\
$2000-2004$ & $2 \%$ & $8 \%$ & $17 \%$ & $4 \%$ & $13 \%$ & $61 \%$ \\
$2005-2009$ & $4 \%$ & $7 \%$ & $23 \%$ & $4 \%$ & $14 \%$ & $67 \%$ \\
$2010-2014$ & $5 \%$ & $12 \%$ & $29 \%$ & $8 \%$ & $15 \%$ & $63 \%$ \\
$2015-2016$ & $3 \%$ & $9 \%$ & $27 \%$ & $10 \%$ & $14 \%$ & $69 \%$ \\
AVERAGE & $\mathbf{3 \%}$ & $\mathbf{9 \%}$ & $\mathbf{2 2 \%}$ & $\mathbf{6 \%}$ & $\mathbf{2 0 \%}$ & $\mathbf{6 4 \%}$ \\
\hline
\end{tabular}

LA\&CA = Latin America and Caribbean

Source: Computed by authors from UNCTAD, world investment report (2018)

\subsection{FDI Inflows to Africa}

Within the context of the low global FDI share and tremendous increases in world FDI, flows to Africa display an exponential increase over the 27 years covered in this study. Whereas the global inward FDI flows increased almost 8.8 times, the corresponding figure for Africa displays an exponential increase of almost 14 times; from an annual average of US\$4355.4 million in the 1990-94 period to US\$60433.9 million in the 2015-16 period (Figure 4).

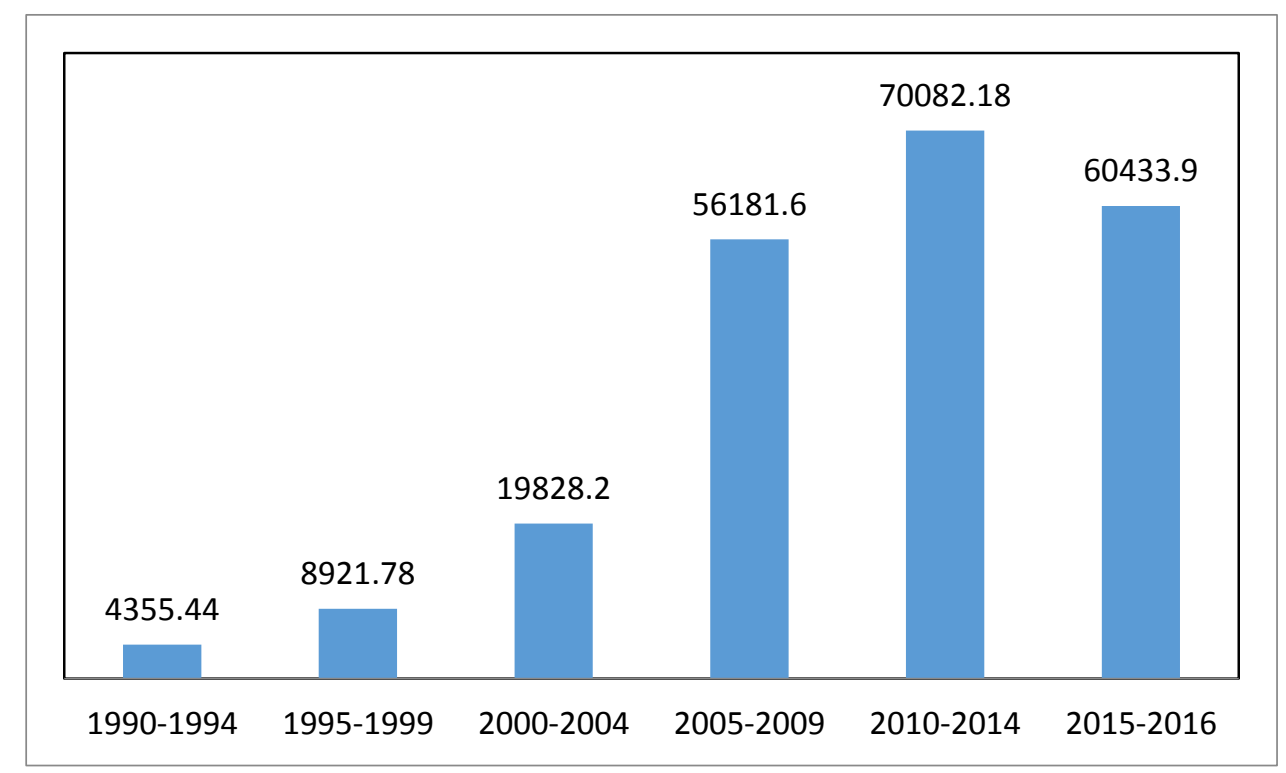

Figure 4. Africa: average flows in US\$ millions

Source: Computed by authors from UNCTAD, world investment report, 2018

\subsection{FDI Inflows to Sub-regions of Africa}

Most FDI that goes to the continent is concentrated in a few sub-regions. Analysis of the FDI into Africa reveals that the small amount of inflows to the continent is not equally distributed among the five sub-regions. Table 3 shows that on average, Southern Africa followed by Northern Africa have been the most popular FDI destinations, receiving 35\% 
and 27\% respectively, of all flows to the continent during the period 1990-2016; East Africa and Central Africa are at the bottom, receiving only $7 \%$ each of the FDI that was attracted to the continent.

Table 3. Share of FDI inflows among African sub-regions

\begin{tabular}{lccccccc}
\hline & $1990-1994$ & $1995-1999$ & $2000-2004$ & $2005-2009$ & $2010-2014$ & $2015-2016$ & Overall Average \\
\hline Southern Africa & $15 \%$ & $37 \%$ & $47 \%$ & $34 \%$ & $40 \%$ & $39 \%$ & $\mathbf{3 5 \%}$ \\
North Africa & $38 \%$ & $26 \%$ & $24 \%$ & $34 \%$ & $18 \%$ & $23 \%$ & $\mathbf{2 7 \%}$ \\
West Africa & $42 \%$ & $27 \%$ & $14 \%$ & $18 \%$ & $21 \%$ & $18 \%$ & $\mathbf{2 3 \%}$ \\
East Africa & $3 \%$ & $8 \%$ & $6 \%$ & $7 \%$ & $9 \%$ & $11 \%$ & $\mathbf{7 \%}$ \\
Central Africa & $2 \%$ & $2 \%$ & $9 \%$ & $6 \%$ & $12 \%$ & $9 \%$ & $\mathbf{7 \%}$ \\
\hline
\end{tabular}

\subsection{FDI Inflows to Resource Rich or Large Countries}

Analysis of the FDI in sub-regions reveals that the FDI is further concentrated on a few countries within that sub-region (Table 4), primarily the large or resource-rich economies, while smaller and resource-poor countries have been largely unable to attract significant FDI inflows. For example, a glance at the two main recipients of FDI in each sub-region reveals that in Southern Africa Angola and South Africa account for 78\% of the FDI that goes into that sub-region; in North Africa Egypt and Morocco account for 59\% of the FDI into that region; in West Africa Nigeria and Ghana take 68\% of the FDI; in East Africa Tanzania and Ethiopia account for $43 \%$ of the FDI into the sub-region; and finally in Central Africa Congo and the Democratic Republic of Congo account take 58\% of the FDI.

Table 5 presents the 15 top FDI recipients in Africa, ranked in descending order of their 27 year mean annual FDI inflows. In addition the country FDI figures are expressed as a percentage of the total FDI into Africa. The rankings for the entire 56 African countries are presented in Appendix 1. The rankings produce several interesting revelations:

1. First, FDI is concentrated within the top 15 recipients which received $81 \%$ of all inflows into the continent during the period 1990-2016; while the remaining 41 countries shared the remaining 19\% of the inflow.

2. Within the context of the top 15 countries, FDI is also concentrated on four FDI destinations, namely, Angola, Nigeria, Egypt and South Africa which received approximately $51 \%$ of all flows to African countries in the study period.

3. The main conclusion from this analysis is that most FDI that goes to the continent is highly concentrated in a few countries, while the majority of countries have been largely unable to attract significant FDI inflows.

\subsection{Sources of FDI Inflows to Africa}

Table 6 shows the cumulative FDI inflows from developed countries to Africa in the period 1981 to 2000, arrayed in descending order of their cumulative totals. Most of the FDI flows during this period came from a small number of investor countries. The United States was the largest investor, followed by the United Kingdom, and France. During this period the United States alone accounted for more than 28 per cent of the total flows from OECD countries, the United Kingdom for 20 per cent and France for 20 per cent. Germany is relatively small investor at a far distance with $9 \%$ of the flows from developed countries. Data for more recent years were not available.

Table 4. Share of FDI inflows among African sub-regions (US\$ Millions)

\begin{tabular}{lcc}
\hline Region & Average 1990-2016 & Per cent of Sub-Region FDI \\
\hline Southern Africa & $\mathbf{1 2 9 3 5 . 0}$ & $\mathbf{1 0 0 \%}$ \\
Angola & $55 \%$ \\
South Africa & $23 \%$ \\
Mozambique & $9 \%$ \\
Zambia & $5 \%$ \\
Namibia & $3 \%$ \\
Botswana & $2 \%$ \\
Malawi & $1 \%$ \\
Zimbabwe & $1 \%$ \\
Lesotho & $0 \%$ \\
Swaziland & $0 \%$
\end{tabular}




\begin{tabular}{|c|c|c|}
\hline Region & Average 1990-2016 & Per cent of Sub-Region FDI \\
\hline North Africa & 8574.8 & $100 \%$ \\
\hline Egypt & & $40 \%$ \\
\hline Morocco & & $19 \%$ \\
\hline Algeria & & $11 \%$ \\
\hline Sudan & & $11 \%$ \\
\hline Tunisia & & $11 \%$ \\
\hline Libya & & $8 \%$ \\
\hline South Sudan & & $0 \%$ \\
\hline West Africa & 6752.1 & $100 \%$ \\
\hline Nigeria & & $53 \%$ \\
\hline Ghana & & $16 \%$ \\
\hline Côte d'Ivoire & & $4 \%$ \\
\hline Liberia & & $4 \%$ \\
\hline Mauritania & & $4 \%$ \\
\hline Niger & & $4 \%$ \\
\hline Benin & & $2 \%$ \\
\hline Guinea & & $2 \%$ \\
\hline Mali & & $2 \%$ \\
\hline Senegal & & $2 \%$ \\
\hline Sierra Leone & & $2 \%$ \\
\hline Burkina Faso & & $1 \%$ \\
\hline Cabo Verde & & $1 \%$ \\
\hline Togo & & $1 \%$ \\
\hline Gambia & & $0 \%$ \\
\hline Guinea-Bissau & & $0 \%$ \\
\hline Saint Helena & & $0 \%$ \\
\hline East Africa & 2754.6 & $100 \%$ \\
\hline Tanzania & & $25 \%$ \\
\hline Ethiopia & & $18 \%$ \\
\hline Uganda & & $15 \%$ \\
\hline Kenya & & $14 \%$ \\
\hline Madagascar & & $11 \%$ \\
\hline Mauritius & & $6 \%$ \\
\hline Seychelles & & $4 \%$ \\
\hline Somalia & & $3 \%$ \\
\hline Djibouti & & $2 \%$ \\
\hline Eritrea & & $1 \%$ \\
\hline Comoros & & $0 \%$ \\
\hline Mayotte & & $0 \%$ \\
\hline Central Africa & 2972.8 & $100 \%$ \\
\hline Congo & & $32 \%$ \\
\hline DR Congo & & $26 \%$ \\
\hline Equatorial Guinea & & $17 \%$ \\
\hline Gabon & & $8 \%$ \\
\hline Cameroon & & $7 \%$ \\
\hline Chad & & $6 \%$ \\
\hline Rwanda & & $3 \%$ \\
\hline Central African Republic & & $1 \%$ \\
\hline Sao Tome and Principe & & $1 \%$ \\
\hline Burundi & & $0 \%$ \\
\hline
\end{tabular}


Table 5. Top 15 FDI recipients and share of inflows to Africa

\begin{tabular}{rlcc}
\hline Rank & Country & Mean Annual FDI 1990-2016 & As a \% of FDI to Africa \\
\hline 1. & Angola & 7103.7 & $21 \%$ \\
2. & Nigeria & 3580.9 & $11 \%$ \\
3. & Egypt & 3402.5 & $10 \%$ \\
4. & South Africa & 2962.6 & $9 \%$ \\
5. & Morocco & 1598.5 & $5 \%$ \\
6. & Mozambique & 1215.9 & $4 \%$ \\
7. & Ghana & 1100.7 & $3 \%$ \\
8. & Algeria & 972.3 & $3 \%$ \\
9. & Tunisia & 965.3 & $3 \%$ \\
10. & Sudan & 949.7 & $3 \%$ \\
11. & Congo & 938.1 & $3 \%$ \\
12. & DR Congo & 766.5 & $2 \%$ \\
13. & Libya & 711.5 & $2 \%$ \\
14. & Tanzania & 696.7 & $2 \%$ \\
15. & Zambia & 622.5 & $2 \%$ \\
16. & Others (41 Countries) & 6399.8 & $19 \%$ \\
\hline
\end{tabular}

Table 6. Accumulated FDI flows from developed countries 1981-2000 (Millions of dollars)

\begin{tabular}{lcccccc}
\hline Country & $\mathbf{1 9 8 1 - 1 9 8 5}$ & $\mathbf{1 9 8 6 - 1 9 9 0}$ & $\mathbf{1 9 9 1 - 1 9 9 5}$ & $\mathbf{1 9 9 6 - 2 0 0 0}$ & TOTALS & \% \\
\hline US & 1866 & 404 & 278 & 9249 & $\mathbf{1 1 7 9 7}$ & $\mathbf{2 8 \%}$ \\
UK & 882 & 2193 & 2376 & 3269 & $\mathbf{8 7 2 0}$ & $\mathbf{2 0 \%}$ \\
France & 1239 & 1001 & 2066 & 4362 & $\mathbf{8 6 6 8}$ & $\mathbf{2 0 \%}$ \\
Germany & 504 & 332 & 402 & 2475 & $\mathbf{3 7 1 3}$ & $\mathbf{9 \%}$ \\
Japan & 350 & 1143 & 201 & 340 & $\mathbf{2 0 3 4}$ & $\mathbf{5 \%}$ \\
Portugal & - & - & 96 & 1560 & $\mathbf{1 6 5 6}$ & $\mathbf{4 \%}$ \\
Italy & 455 & 217 & 213 & 678 & $\mathbf{1 5 6 3}$ & $\mathbf{4 \%}$ \\
Netherlands & 94 & 153 & 297 & 816 & $\mathbf{1 3 6 0}$ & $\mathbf{3 \%}$ \\
Canada & 27 & 37 & 146 & 626 & $\mathbf{8 3 6}$ & $\mathbf{2 \%}$ \\
Switzerland & -6 & 73 & 452 & 69 & $\mathbf{5 8 8}$ & $\mathbf{1 \%}$ \\
Spain & - & - & 50 & 476 & $\mathbf{5 2 6}$ & $\mathbf{1 \%}$ \\
Sweden & 177 & 48 & 4 & 197 & $\mathbf{4 2 6}$ & $\mathbf{1 \%}$ \\
Denmark & 19 & 24 & 1 & 340 & $\mathbf{3 8 4}$ & $\mathbf{1 \%}$ \\
Belgium & 99 & 40 & -47 & 242 & $\mathbf{3 3 4}$ & $\mathbf{1 \%}$ \\
Austria & 72 & 33 & 7 & 221 & $\mathbf{3 3 3}$ & $\mathbf{1 \%}$ \\
Norway & 99 & 12 & 145 & -148 & $\mathbf{1 0 8}$ & $\mathbf{0 \%}$ \\
Finland & - & 38 & 3 & 8 & $\mathbf{4 9}$ & $\mathbf{0 \%}$ \\
Australia & -13 & -149 & -33 & -99 & $\mathbf{- 2 9 4}$ & $\mathbf{- 1 \%}$ \\
TOTALS & $\mathbf{5 8 6 4}$ & $\mathbf{5 5 9 9}$ & $\mathbf{6 6 5 7}$ & $\mathbf{2 4 6 8 1}$ & $\mathbf{4 2 8 0 1}$ & $\mathbf{1 0 0 \%}$ \\
\hline
\end{tabular}

Adapted from: UNCTAD (2002:51) quoted as based on unpublished data from members of the OECD's Development Assistance (DAC) Committee.

\subsection{Sectorial Distribution of FDI in Africa}

Data from OECD investor countries shows that the primary or extractive sector has been the main recipient of FDI, with a share of 55\% in the accumulated FDI to Africa during the period 1996-2000 while the secondary or manufacturing sector was the least at 20\% (Table 7). According to UNCTAD (2002:52) oil and petroleum are largely responsible for the performance of the primary sector. Data for the recent period 2010-2017 shows that the tertiary or services sector has gained in importance and outstripped primary sector inflows, to reach 55\% of the total FDI inflows, thus reversing the previous trend. In this period the primary sector is receiving the least FDI at $16 \%$ (Table 8). In the services sector, the largest FDI goes in the financial sector, infrastructure such as electricity, telecommunications and water as well as business services, real estate, gas and water (UNCTAD, 2008:42). In general in both periods the manufacturing sector has not been leading in FDI intake and in fact in most cases the continent lags behind in the other two sectors. 
Table 7. FDI outflows from OECD investors to Africa, by sector, 1996-2000 (millions of dollars and per cent)

\begin{tabular}{lccccccc}
\hline Sector & $\mathbf{1 9 9 6}$ & $\mathbf{1 9 9 7}$ & $\mathbf{1 9 9 8}$ & $\mathbf{1 9 9 9}$ & $\mathbf{2 0 0 0}$ & $1996-2000$ & $\%$ \\
\hline Primary & 3133 & 4369 & 5056 & 2726 & 2029 & $\mathbf{1 7 3 1 4}$ & $\mathbf{5 5 \%}$ \\
Secondary & 1085 & 1114 & 1233 & 1812 & 1297 & $\mathbf{6 5 4 1}$ & $\mathbf{2 0 \%}$ \\
Tertiary & 624 & 255 & 52 & 308 & 1931 & $\mathbf{7 8 7 1}$ & $\mathbf{2 5 \%}$ \\
Total & $\mathbf{4 8 4 2}$ & $\mathbf{7 6 3 9}$ & $\mathbf{6 3 4 1}$ & $\mathbf{7 6 4 7}$ & $\mathbf{5 2 5 7}$ & $\mathbf{3 1 7 2 6}$ & $\mathbf{1 0 0 \%}$ \\
\hline
\end{tabular}

Source: UNCTAD (2002:52): world investment report 2002

Table 8. Announced Greenfield FDI projects by industry 2010-2017 (US\$ millions)

\begin{tabular}{lcccccccccc}
\hline Sector & $\mathbf{2 0 1 0}$ & $\mathbf{2 0 1 1}$ & $\mathbf{2 0 1 2}$ & $\mathbf{2 0 1 3}$ & $\mathbf{2 0 1 4}$ & $\mathbf{2 0 1 5}$ & $\mathbf{2 0 1 6}$ & $\mathbf{2 0 1 7}$ & $\mathbf{2 0 1 0 - 2 0 1 7}$ & \% \\
\hline Primary & 20237 & 22824 & 7479 & 5735 & 21974 & 15841 & 3713 & 10574 & $\mathbf{1 0 8 3 7 7}$ & $\mathbf{1 6 \%}$ \\
Secondary & 39506 & 31205 & 21129 & 13851 & 29270 & 18819 & 19357 & 21060 & $\mathbf{1 9 4 1 9 7}$ & $\mathbf{2 9 \%}$ \\
Tertiary & 29175 & 28286 & 18847 & 34010 & 37890 & 36687 & 94039 & 85305 & $\mathbf{3 6 4 2 3 9}$ & $\mathbf{5 5 \%}$ \\
Total & $\mathbf{8 8 9 1 8}$ & $\mathbf{8 2 3 1 5}$ & $\mathbf{4 7 4 5 5}$ & $\mathbf{5 3 5 9 6}$ & $\mathbf{8 9 1 3 4}$ & $\mathbf{7 1 3 4 7}$ & $\mathbf{1 1 7 1 0 9}$ & $\mathbf{1 1 6 9 3 9}$ & $\mathbf{6 6 6 8 1 3}$ & $\mathbf{1 0 0 \%}$ \\
\hline
\end{tabular}

Source: UNCTAD (2012, 2014, 2016, 2018): world investment reports

\section{Discussion and Conclusions}

\subsection{Discussion}

This section presents discussions and conclusions of the study. There is evidence to show that in the 27 -year period between 1990 and 2016 there has been an astronomical increase in global FDI. This may be explained by increasing globalization trends especially rapid advances and diffusion of technology in transport and communication. There is also evidence to suggest that when African countries pursued inward-looking strategy that discouraged FDI it had adverse effect on economic growth. On the other hand there is evidence to show that when Africa had a regime shift in favor of outward-looking development strategies including encouraging FDI, this coincided with a relative improvement in economic performance in several African countries. The improvement is most likely as a result of the change in policy framework. This suggests that African countries should take FDI policies as an important component in their macro-economic planning for it seems to have a significant positive impact on economic development.

On a global and regional level of distribution, FDI flows into the developed countries were disproportionately high when compared to the developing countries. It is ironical that developing nations who are most in need of FDI because of having scarcity of capital and resources are not able to attract as much FDI compared to advanced countries. It is therefore important for developing countries to study the aspects of their economy or government that are heavily scrutinized by firms that are considering a possible long-term investment. A good understanding of these factors would help attract and retain FDI.

Analysis of FDI into Africa shows that although FDI to Africa has been growing, the continent's share of global FDI is very small. Even when compared with other developing regions, Africa still remains a marginal player in attracting FDI. The implication of this finding for Africa is that the continent has to work harder than the rest of the developing world in improving the aspects of their economy or government that are heavily scrutinized by firms that are considering a possible long-term investment.

The little FDI that comes to Africa is concentrated sub-regionally and country-wise. Most FDI that goes to the continent is concentrated on Southern Africa followed by Northern Africa. East Africa and Central Africa are at the bottom. The FDI is further concentrated on a few countries within each continent's region. For example, in Southern Africa Angola and South Africa account for 78\%. The pattern is the same in the other sub-regions of Africa. In this context, one of the challenges facing African countries is how to reduce the geographic concentration of FDI flows in order to maximize the developmental impact of FDI on the whole continent.

Apart from sub-regional and country-wise concentration, the FDI that comes into the continent is further concentrated sector-wise. Past data shows that Africa used to receive FDI mostly in the primary (extractive) sector, as a result the benefits to the region have not been as significant as in East Asia where FDI was mainly into the secondary (manufacturing) sector. On the other hand, more recent data shows that FDI is coming mostly into the tertiary (services). The main conclusion is that the secondary or manufacturing sector has never been the main 
recipient of FDI for a sustained period of time. This fact also explains why, despite impressive growth trends, African countries have not made effective use of FDI to support development, as evidenced by the fact that FDI has generated few linkages in African economies, and has not led to significant technology transfer as expected. In this regard, a key challenge facing Africa is how to attract more FDI in dynamic sectors with high income elasticity of demand. On the positive note, although FDI flows to Africa go mostly to the extractive sector, there are indications that a sectoral shift is occurring particularly into services. In fact, data on greenfield projects over the past few years indicate that the relative importance of the extractive sector is declining. Much of the FDI is invested in locations that have natural resources such as gas, oil and other minerals. Countries such a Nigeria, Angola, Ethiopia and DRC Congo offer a combination of markets, strategic assets and natural resources advantages allowing ownership and internalization. Countries such as South Africa, Egypt, Kenya and Algeria provide market and efficiency advantages. On the other hand countries that offer less advantages on combination of natural resources market efficiency or strategic asset have attracted minimum inflow of FDI; a phenomenon that can be addressed by change of policy and business climate.

FDI does not only flow vertically from developed economies to less developed economies but also horizontally among developed economies as well as among less developed economies depending on the advantages accrued. Countries like South Africa, Egypt and Libya were sources of FDI to several African countries over the last decades of the 90s and 2000s with their firms seeking market and natural resource advantages. This is consistent with the eclectic theory. There is evidence of concentration in the investor countries. Most of the FDI flows during the 1996-2000 period came from a number of investor concentrated in few countries led by the United States, followed by the United Kingdom and France. This conclusion must be treated with caution for two reasons: the data is based on data from OECD countries only and it is outdated; more recent data were not available.

\subsection{Conclusions}

The overall conclusion is that global and African FDI trends show that FDI is a growth point that countries can count on as a source of resources for development. It is ironic that Africa, the continent which is in dire need for FDI, attracts a very small share of FDI inflows in relative terms. It may be speculated that one of the reasons for the low share in global FDI flows to Africa and the limited impact of FDI on the continent is the approach adopted by African countries in promoting FDI, which focuses more on providing incentives and less on creating a domestic environment conducive to entrepreneurship and business in general. The experience in Asia has shown that the most effective way to attract market-seeking or efficiency-seeking FDI is to have a dynamic and growing private sector and a policy environment attractive to both domestic and foreign investors. There is, therefore, a need for African countries to rethink their investment promotion strategy to ensure that it yields maximum benefits to the continent.

\section{References}

Akinlo, A.E. (2003). Foreign direct investment and and economic growth in Sub-Saharan Africa. International Review of Economics and Business, 50, 569-580.

Anyanwu, J.C. (2003). Promoting Investment in Africa. Tunis.

Anyanwu, J.C., \& Erhijakpor, A.E. (2003). Trends and Determinants of Foreign Direct Investment in Africa. Tunis: African Development Bank.

Asiedu, E. (2002). On the determinants of foreign direct investment to developing countries: Is Africa different? World Develpment, 30, 107-119. https://doi.org/10.1016/S0305-750X(01)00100-0

Bende-Nabenfe, A. (2002). Foreign direct investment dterminants in Sub-Saharan Africa: a cointegration analysis. Economics Bulletin, 6, 1-19.

Bezuidenhout, H., \& Kleynhans, E. (2015). Implications of foreign direct investment for national sovereignty: The Wal Mart/Massmart merger as an illustration. South African Journal of International Affairs, 22(1), 93-110. https://doi.org/10.1080/10220461.2015.1009155

Brooks, D.H., Fan, E.X., \& Sumulo, L.R. (2003). Foreign Direct Investment in Developing Asia: Trends, Effects, and Likely Issues for the Forthcoming WTO Negotiations. Asia: Asian Development Bank.

Cockcroft, L., \& Riddell, R.C. (1991). Foreign Direct Investment in Sub-Saharan Africa. Washington: The World Bank.

Dunning, J.F. (1977). Trade location of economic activity and the MNE: A search of an eclectic approach. In B. Ohlin, P. O. Hesselborn, \& P. J. Wijkman (Eds.), The International Allocation of Economic Activity. 
Dunning, J.H., \& Lundan, S.M. (2008). Multinational Enterprises and The Global Economy. Cheltenham: Edward Elgar Publishing.

Dupasquier, C., \& Osakwe, P. (2005). Foreign direct investment in Africa: Challenges and Responsibilities. Addis Ababa: African Trade Policy Centre.

EIA. (2003). Nigeria: environmental issues. Country Analysis Briefs, Energy Information Administration. US Department of Energy.

Hayami, Y. (2001). Development Economics: From Poverty Alleviation to the Wealth Of Nations (2nd ed.). New York: Oxford University Press. https://doi.org/10.1093/0199243972.001.0001

Kurtishi-Kastrati, S. (2013). Impact of FDI on economic growth: An overview of the main theories of FDI and empirical research. European Scientific Journa, 9(7).

Lemi, A., \& Asefa, S. (2003). Foreign direct investment and uncertainty: empirical evidence from Africa. Africa Finance journal, 5, 36-67.

Loots, E., \& Kabundi, A. (2012). Foreign direct investment to Africa: trends, dynamics and challenges. South African Journal of Economic and Management Sciences, 15(2). https://doi.org/10.4102/sajems.v15i2.148

Ndulu, B.J., Chakraborti, L., Lijane, L., Ramachandran, V., \& Wolgin, J. (2007). Challenges of African growth: opportunities, constraints, and startegies. Washington DC: The World Bank Publications. https://doi.org/10.1596/978-0-8213-6882-4

Nuno, C., \& Fontoura, M.P. (2007). Determinant Factors of FDI Spillovers- What do We Really Know? World Development, 35(3), 410-425. https://doi.org/10.1016/j.worlddev.2006.04.001

Ohlin, B. (1933). Interregional and international trade. Cambridge: Harvard University Press.

Pavithra, J. (2012). A Study on the Role of Foreign Direct Investment in Retail industry in India. International Journal of Innovative Research in Science, Engineering and Technology, 1(1). Retrieved from www.ijirset.com

Population, A. (2018, June). Africa Population. Retrieved from http://worldpopulationreview.com/continents/africa-population/

Rodrik, D. (1998). Trade policy and economic performance in Sub-Saharan Africa. National Bureau of Economic Research. https://doi.org/10.3386/w6562

Rogoff, K., \& Reinhart, C. (2003). FDI to Africa: the role of price stability and currency instability. Washington: International Monetary Fund.

UNCTAD. (1991). World Investment Report 1991: The Triad in Foreign Direct Investment. New York: United Nations Centre on Transnational Corporations.

UNCTAD. (2002). World Investment Report 2002 Transnational Corporations and Export Competitiveness. New York and Geneva: UNCTAD.

UNCTAD. (2008). World Investment Report 2008: Transnational Corporations and the Infrastructure Challenge. Geneva: UNCTAD.

UNCTAD. (2018). UNCTAD, FDI/MNE database. Geneva: United Nations Conference on Trade and Develpoment. Retrieved August 28, 2018, from http://www.unctad.org/en/Pages/DIAE/World\%20Investment\%20Report/Annex-Tables.aspx

UNCTAD. (2018). World Investment Report: Annex Tables, FDI inflows by region and economy 1990-2017. UNCTAD. $\quad$ Retrieved June $6, \quad$ 2018, from www.unctad.org/en/Pages/DIAE/World\%20Investment\%20Report/Annex-Tables.aspx

World Bank. (1999). Foreign Direct Investment in Bangladesh: Issues of Long-run.

World Bank. (2003). Global Economic Prospects and the Developing Countries. Washington DC: World Bank.

World Bank. (2017). World Development Indicators 2017-Open Knowledge Repository. New York: UNCTAD.

Appendix 1. Mean FDI 1990-2016 and as \% of inflow to Africa

\begin{tabular}{llcc}
\hline Country & Mean 1990-2016 & Percent of FDI to Africa \\
\hline 1. & Angola & 7103.7 & $21 \%$ \\
2. Nigeria & 3580.9 & $11 \%$ \\
3. & Egypt & 3402.5 & $10 \%$
\end{tabular}




\begin{tabular}{|c|c|c|}
\hline Country & Mean 1990-2016 & Percent of FDI to Africa \\
\hline 4. South Africa & 2962.6 & $9 \%$ \\
\hline 5. Morocco & 1598.5 & $5 \%$ \\
\hline 6. Mozambique & 1215.9 & $4 \%$ \\
\hline 7. Ghana & 1100.7 & $3 \%$ \\
\hline 8. Algeria & 972.3 & $3 \%$ \\
\hline 9. Tunisia & 965.3 & $3 \%$ \\
\hline 10. Sudan & 949.7 & $3 \%$ \\
\hline 11. Congo & 938.1 & $3 \%$ \\
\hline 12. DR Congo & 766.5 & $2 \%$ \\
\hline 13. Libya & 711.5 & $2 \%$ \\
\hline 14. Tanzania & 696.7 & $2 \%$ \\
\hline 15. Zambia & 622.5 & $2 \%$ \\
\hline 16. Ethiopia & 503.2 & $1 \%$ \\
\hline 17. Equatorial Guinea & 496.2 & $1 \%$ \\
\hline 18. Uganda & 410.4 & $1 \%$ \\
\hline 19. Kenya & 393.4 & $1 \%$ \\
\hline 20. Namibia & 384.1 & $1 \%$ \\
\hline 21. Madagascar & 308.6 & $1 \%$ \\
\hline 22. Côte d'Ivoire & 302.3 & $1 \%$ \\
\hline 23. Botswana & 269.4 & $1 \%$ \\
\hline 24. Niger & 248.8 & $1 \%$ \\
\hline 25. Mauritania & 248.1 & $1 \%$ \\
\hline 26. Liberia & 246.7 & $1 \%$ \\
\hline 27. Gabon & 234.5 & $1 \%$ \\
\hline 28. Cameroon & 213.7 & $1 \%$ \\
\hline 29. Chad & 191.8 & $1 \%$ \\
\hline 30. Senegal & 168.4 & $0 \%$ \\
\hline 31. Mauritius & 165.8 & $0 \%$ \\
\hline 32. Mali & 164.6 & $0 \%$ \\
\hline 33. Sierra Leone & 151.6 & $0 \%$ \\
\hline 34. Zimbabwe & 148.9 & $0 \%$ \\
\hline 35. Guinea & 128.3 & $0 \%$ \\
\hline 36. Malawi & 109.5 & $0 \%$ \\
\hline 37. Benin & 108.1 & $0 \%$ \\
\hline 38. Seychelles & 101.4 & $0 \%$ \\
\hline 39. Burkina Faso & 99 & $0 \%$ \\
\hline 40. Rwanda & 94.5 & $0 \%$ \\
\hline 41. Togo & 86.5 & $0 \%$ \\
\hline 42. Cabo Verde & 76 & $0 \%$ \\
\hline 43. Somalia & 72.9 & $0 \%$ \\
\hline 44. Djibouti & 61.6 & $0 \%$ \\
\hline 45. Lesotho & 60.9 & $0 \%$ \\
\hline 46. Swaziland & 57.5 & $0 \%$ \\
\hline 47. Eritrea & 34.8 & $0 \%$ \\
\hline 48. Gambia & 32.4 & $0 \%$ \\
\hline 49. Central African Republic & 19.2 & $0 \%$ \\
\hline 50. Sao Tome and Principe & 15 & $0 \%$ \\
\hline 51. Guinea-Bissau & 9.9 & $0 \%$ \\
\hline 52. Comoros & 3.6 & $0 \%$ \\
\hline 53. Burundi & 3.3 & $0 \%$ \\
\hline 54. Mayotte & 0 & $0 \%$ \\
\hline 55. Saint Helena & -0.1 & $0 \%$ \\
\hline 56. South Sudan & -25 & $0 \%$ \\
\hline AFRICA & 33987.2 & $100 \%$ \\
\hline
\end{tabular}

